\title{
Comparison of the toxicity and repellency of two conventional neoni- cotinoids and a coconut-derived insecticide soap toward the parasitoid wasp Aphelinus mali Haldeman, 1851
}

\author{
Asgar EBADOLLAHI ${ }^{1,2}$ and Reza SADEGHI ${ }^{3}$
}

Received December 1, 2019; accepted January 8, 2020.

Delo je prispelo 1. decembra 2019, sprejeto 8. januarja 2020.

Comparison of the toxicity and repellency of two conventional neonicotinoids and a coconut-derived insecticide soap toward the parasitoid wasp Aphelinus mali Haldeman, 1851

Abstract: The parasitoid wasp Aphelinus mali Haldeman, 1851 (Hymenoptera: Aphelinidae) is the most important biological control agent against the woolly apple aphid, Eriosoma lanigerum (Hausemann, 1802) (Hemiptera: Aphididae), which is an important apple orchards pest throughout the world. Based on the importance of using low-risk compounds to protect beneficial agents, the present study was carried out to evaluate the toxic and repellent effects of two conventional chemicals (imidacloprid and thiacloprid) and coconut-derived biopesticide soap (Palizin ${ }^{\oplus}$ ) toward A. mali. The results of residual bioassays on apple leaf discs indicated that imidacloprid after $24 \mathrm{~h}$ and insecticide soap after $72 \mathrm{~h}$ exposure time categorized at the highest and no/little toxicity rates, respectively. Ingestion bioassays on filter papers revealed that imidacloprid and thiacloprid had moderate toxicity rate, while insecticide soap had a low-level toxicity rate. Repellency test at Y-tube olfactometer showed that the repellent effects of both chemicals were more than that of insecticide soap. It is concluded that coconut-derived soap was compatible with the parasitoid activity, and the caution should be paid when including the two neonicotinoid insecticides imidacloprid and thiacloprid for E. lanigerum management.

Key words: Eriosoma lanigerum; Aphelinus mali; insecticides; toxicity; repellency
Primerjava strupenosti in odvračalnega delovanja dveh konvencionalnih neonikotinoidov in insekticidnega mila iz kokosa na krvavkinega najezdnika (Aphelinus mali Haldeman, 1851)

Izvleček: Parazitoidna osica krvavkin najezdnik (Aphelinus mali Haldeman, 1851, Hymenoptera: Aphelinidae) je najpomembnejši naravni sovražnik krvave uši (Eriosoma lanigerum [Hausemann, 1802], Hemiptera: Aphididae), ki je pomemben škodljivec jablan širom po svetu. Zaradi vse večjega pomena okoljsko sprejemljivejših snovi pri zatiranju rastlinskih škodljivcev, saj na ta način varujemo tudi koristne žuželke, smo v raziskavi ovrednotili toksične in repelentne učinke dveh konvencionalnih kemičnih sredstev za varstvo rastlin (imidakloprid in tiakloprid) in bioinsekticidnega mila (Palizin $^{\oplus)}$ iz kokosa na vrsto A. mali. Rezultati poskusa na diskastih izsečkih jabolčnih listov so pokazali, da sta imela imidakloprid $24 \mathrm{~h}$ po nanosu in insekticidno milo $72 \mathrm{~h}$ po nanosu največji učinek na uši in nič ali le malo strupenega učinka na parazitoida. Prehranjevalni poskus na filtrirnem papirju je pokazal, da sta imela imidakloprid in tiakloprid zmeren toksični učinek, medtem, ko je imelo insekticidno milo zelo majhnega. Preizkusi odvračalnega delovanja snovi v Y-cevastem olfaktometru so pokazali, da so bili odvračalni učinki obeh kemikalij večji kot pri insekticidnem milu. Zaključimo lahko, da je kokosovo milo kompatibilno s parazitoidom, več pozornosti pa je potrebno nameniti, kadar za zatiranje krvave uši uporabimo oba neonikotinoidna insekticida, imidakloprid in tiakloprid.

Ključne besede: Eriosoma lanigerum; Aphelinus mali; insekticidi; toksičnost; repelenca

1 University of Mohaghegh Ardabili, Moghan College of Agriculture and Natural Resources, Ardabil, Iran

2 Corresponding author, e-mail: ebadollahi@uma.ac.ir

3 University of Tehran, College of Abouraihan, Department of Entomology and Plant Pathology, Tehran, Iran 


\section{INTRODUCTION}

The woolly apple aphid (Eriosoma lanigerum (Hausemann, 1802), Homoptera: Aphididae) is important pest in apple orchards. It can causes significant damages to the apple trees by sucking the sap from new shoots and branches (Rogers et al., 2011; Lordan et al., 2015). Its feeding activity leads to the formation of galls on woody tissue and young shoots. Buds can be destroyed and apple calyces may also be contaminated with the aphid honeydew and sooty molds (Beers et al., 2007). The woolly aphid parasitoid [Aphelinus mali Haldeman, 1851, (Hymenoptera: Aphelinidae)], is a specific and very efficient endoparasitoid of E. lanigerum that had been introduced from North America to other apple-growing regions of the world, such as in Iran (Heunis \& Pringle, 2003, Su et al., 2017).

Although the application of synthetic insecticides is the conventional method for the management of $E$. lanigerum, such strategy can have various negative side effects, such as impact on non-target organisms, pest resistance and threats to human health (Desneux et al., 2007; Damalas \& Eleftherohorinos, 2011). For example, organic phosphorus insecticides, which are widely applied to reduce populations of E. lanigerum, cause severe damage in its parasitoid wasp populations (Beers et al., 2007). Recent researches have shown that the chemical agents have lethal and sublethal effects on the hymenopterous parasitoids. For example, Desneux et al. (2004) indicated that lambda-cyhalothrin had a high toxicity on Aphidius ervi Haliday, 1834 (Aphidiinae). Further, low doses of this chemical weakened the orientation behavior of A. ervi. Toxic effects of the deltamethrin and its negative effects on recolonization capacities of A. ervi was also documented (Desneux et al., 2006). The adults of egg parasitoid wasp Trichogramma chilonis Ishii, 1941 (Trichogrammatidae) were very susceptible to chlorfenapyr, fipronil, spinosad, avermectins, ß-cypermethrin, and cartap (Wang et al., 2012). In other study, acute toxicity of mineral oil and pyriproxyfen (a juvenile hormone mimic) was tested against the parasitoid wasp Aphytis melinus DeBach, 1959 (Aphelinidae). Mineral oil had high mortality on the adults of A. melinus, but pyriproxyfen had neither lethal nor sublethal effects. However, parasitoid larvae were very susceptible to pyriproxyfen (Biondi et al., 2015).

Accordingly, the application of suitable chemical control tools that can reduce the side effects of pesticides and prevent damage to a pest's natural enemies is necessary. The aim of the present study was, therefore, to assess the non-target toxicity of two conventional neonicotinoids imidacloprid and thiacloprid and a novel coconut-derived bioinsecticide soap (Palizin") on the parasitoid wasp A. mali adults in the experimental conditions.

\section{MATERIALS AND METHODS}

\subsection{TEST INSECT}

All bioassays were conducted using a parthenogenetic (all females) strain of $A$. mali. Apple branches ('Red Delicious') infested with E. lanigerum were collected from apple orchards at Miami County (Semnan province, Iran) $\left(36^{\circ} \mathrm{N} 55^{\circ} \mathrm{E}\right)$, in June 2016 , and placed in one-liter flasks until emergence of the parasitoid wasps. Prior to the experiment, the A. mali colony was reared for 3 to 4 generations in an incubator at $27 \pm$ $1{ }^{\circ} \mathrm{C}, 55 \pm 5 \%$ Relative Humidity (RH) and $14 \mathrm{~L}: 10 \mathrm{D}$ photoperiod, using apple leaves infested with E. lanigerum. Adult parasitoids were kept in glass tubes and fed on $10 \%$ honey-water solution smeared inside the test tubes' wall.

\subsection{INSECTICIDES}

Three commercial formulations of insecticides were used in the present study: imidacloprid concentrate suspension (Confidor), provided as a commercial product by Paksame Iranian Company with $35 \%$ active ingredient, thiacloprid (Calypso) concentrate suspension, provided as a commercial product formulized by Bayer Company with $48 \%$ active ingredient, and the coconut soap (Palizin') as concentrate suspension was purchased from Iranian Kimia Sabzavar Company with $65 \%$ active ingredient. For bioassays, maximum recommended concentrations were used: $0.5,0.2$ and $1.5 \mathrm{ml} \mathrm{l}^{-1}$ insecticide/distilled water imidacloprid, thiacloprid and the insecticide soap, respectively.

\subsection{RESIDUAL CONTACT BIOASSAY ON APPLE LEAVES}

Fresh apple leaves (Malus pumila Miller) were sampled from apple orchards, which had no history of chemical control in the past three years. Fresh apple leaves were sprayed by recommended concentrations of insecticides until runoff by using a hand sprayer (Williams et al., 2003). The leaves were put into a chemical hood for an hour and then transferred to Petri dishes, $9 \mathrm{~cm}$ of diameter. Twenty-five, one-day-old female parasitoids were placed in each Petri dish, and then the dishes were kept at room conditions at $27 \pm 1{ }^{\circ} \mathrm{C}$ and 55 
$\pm 5 \mathrm{RH}$. In the untreated control groups, distilled water was used instead of insecticide concentrations. Each experiment was repeated four times and mortality was recorded 24,48 and $72 \mathrm{~h}$ after the exposure beginning.

\subsection{INGESTION BIOASSAY ON FILTER PAPER}

To improve the feeding of the parasitoid adults and to mimic the field situation where they custom external nutrients, the same mentioned concentrations were prepared by adding $10 \%$ of sugar. The filter papers $(5 \mathrm{~cm}$ of diameter) was soaked in one $\mathrm{ml}$ of the solutions and were placed in the center of the $9 \mathrm{~cm}$ Petri dishes (Rogers et al., 2011). Twenty-five parasitoid adults were transferred to each Petri dish under the laboratory conditions as described above. In the control groups, distilled water with $10 \%$ sugar was also used instead of insecticides. The experiment was repeated 4 times and mortality rates was recorded $72 \mathrm{~h}$ post exposure.

\subsection{REPELLENT EFFECT}

The Y-tube olfactometer was assembled by 3 linked glass tubes (each $10 \mathrm{~cm}$ long and $1 \mathrm{~cm}$ in diameter). The flow of air was established by an adjustable fan. To evaluate the repellency of the insecticides, infested apple leaves with 15 adult females of aphids were sprayed at the recommended concentrations and allowed to dry for one hour under test conditions. The insecticide-treated leaves were inserted in one of the openings of the Y-tube olfactometer and the other opening was considered as a control. The control groups consisted of leaves treated only with distilled water. Thirty adult parasitoids were released inside a one-liter glass container covered by a black cloth for stimulating the wasps to move from darkness to light, thus allowing the selection of one of the arms of the device. Number of insects were recorded on each side of the tube every $3 \mathrm{~h}$ for 18-hour duration. Y-tube olfactometer was kept in experimental conditions with $27 \pm 1^{\circ} \mathrm{C}$ and $55 \pm 5 \mathrm{RH}$ and tests were repeated 3 times (Sadeghi et al., 2014).

\subsection{DATA ANALYSIS}

Data of parasitoid mortality in the bioassays were corrected using Abbott's formula (Abbott, 1925) when mortality was observed in the control groups. Data analysis was carried out by SPSS software (Version 24). Data obtained after 24, 48 and $72 \mathrm{~h}$ of residual exposure and those from the ingestion bioassay were checked for normality using the Kolmogorov-Smirnov test. All data were normally distrib- uted and thus the one-way analysis of variance (ANOVA) was run for each dataset. Mean separation was assessed using the Tukey's post hoc test at $p \leq 0.05$. Insecticide toxicity was rated according to IOBC toxicity categories (Sterk et al., 1999): (1) harmless, (2) slightly harmful, (3) moderately harmful, and (4) harmful (corresponding to reductions below $30 \%$, between $31-79 \%$, between $80-99 \%$ and higher than $99 \%$, respectively). Percentage repellency (PR) was calculated as follows: $\mathrm{PR}=[(\mathrm{C}-\mathrm{T}) /(\mathrm{C}+\mathrm{T})] \times 100$, where $\mathrm{C}=$ number of wasps on the treated area with distilled water, and $\mathrm{T}=$ number of wasps on the area treated with insecticide (Nerio et al., 2009). Classification of PR values was done according to Juliana and $\mathrm{Su}$ (1983): class $0(\mathrm{PR}=$ $0.1 \%)$, class I $(\mathrm{PR}=0.1-20 \%)$, class II $(\mathrm{PR}=20.1-40 \%)$, class III (PR $=40.1-60 \%)$, class IV $(\mathrm{PR}=60.1-80 \%)$ and class V $(\mathrm{PR}=80.1-100 \%)$.

\section{RESULTS}

\subsection{RESIDUAL CONTACT BIOASSAY}

In the residual contact bioassay on apple, although all the insecticides caused significant mortality $(F=75.044$, $\mathrm{df}=2,11, p<0.001)$ after $24 \mathrm{~h}$, imidacloprid caused the highest rate of parasitoid mortality (78.850 $\pm 4.703 \%)$; while insecticide soap caused the lowest mortality (28.351 $\pm 2.413 \%)$ at this duration. Mortality was also statistically significant after $48(F=274.485, \mathrm{df}=2,11, p<0.001)$ and $72(F=209.515, \mathrm{df}=2,11, p<0.001) \mathrm{h}$. In general, the mortality rates decreased as time pass due to reduction in residual concentrations. For example, mortality significantly decreased from $32.609 \pm 2.413 \%$ at the 24 hour exposure time to $16.304 \pm 2.030 \%$ after $72 \mathrm{~h}$ for thiacloprid (Figure 1 and Table 1). Observed mean mortality in the control groups were $5.00 \pm 0.25 \%$ after 24,48 and $72 \mathrm{~h}$. Toxicity ratings for insecticidal activity of imidacloprid, thiacloprid and insecticide soap in bioassays with apple leaves are also shown in Table 1. According to toxicity rating of IOBC, imidacloprid had moderately harmful effect after 24-hour and insecticide soap had lowest toxicity (harmless) after 72 hour exposure period (Table 1).

\subsection{INGESTION BIOASSAY}

All tested insecticides had significant effects on the parasitoid mortality $(F=174.915, \mathrm{df}=2,11, p<0.001)$ in the ingestion bioassays. After $72 \mathrm{~h}$ of exposure, imidacloprid caused the highest rate of parasitoid mortality $(69.042$ $\pm 1.011 \%)$ and insecticide soap showed the lowest rate of mortality $(29.875 \pm 1.628 \%)$. However, insignificant differences were found between imidacloprid and thiaclo- 


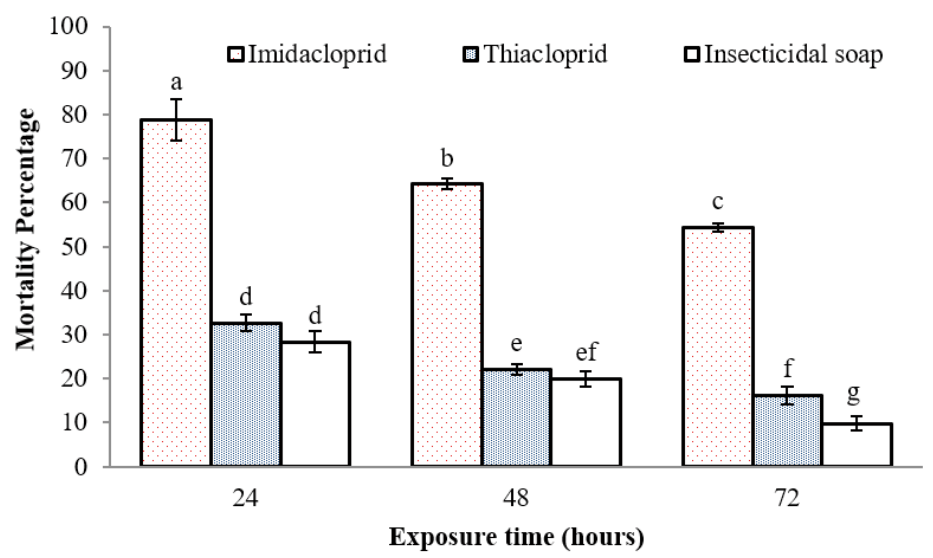

Figure 1: Mean percentage mortality $( \pm$ SE) of Aphelinus mali females after exposure to dry residues of imidacloprid, thiacloprid and a coconut-derived insecticide soap on apple leaves. Mortalities (\%) compared with Tukey's test at $p \leq 0.05$ in which same letters are not significantly different.

Table 1: International Organization for Biological Control (IOBC) toxicity classes for Aphelinus mali females exposed to dry residues in apple leaves or that have fed on sugary solutions contaminated with imidacloprid, thiacloprid and insecticide soap

\begin{tabular}{llll}
\hline Bioassay & Insecticide & Exposure Time $(\mathrm{h})$ & Toxicity Rating \\
\hline Residual Contact & imidacloprid & 24 & moderately harmful \\
& & 48 & slightly harmful \\
slightly harmful & slightly harmful & harmless & harmless \\
& thiacloprid & 72 & harmless \\
& & 24 & harmless \\
& & 48 & harmless \\
\hline ingestion & & 24 & slightly harmful \\
& & 48 & slightly harmless \\
& imidacloprid & 72 & harmless \\
\hline
\end{tabular}

Classification of PR values followed that cited in Juliana and Su (1983): Harmless, slightly harmful, moderately harmful, and harmful corresponding to mortality below $30 \%$, between 31 and $79 \%$, between 80 and $99 \%$ and higher than $99 \%$, respectively.

prid (Table 1and Figure 2). Observed mean mortality in the control groups was $3.0 \%$ after $72 \mathrm{~h}$. Rating of insecticide toxicity indicated that imidacloprid and thiacloprid were slightly harmful while insecticide soap was harmless against $A$. mali (Table 1 ). In general, coconut-derived insecticide soap had lower toxicity against $A$. mali than the chemical insecticides: imidacloprid and thiacloprid in both bioassays with apple leaves and filter papers.

\subsection{REPELLENT EFFECT}

The repellent activity of the two neonicotinoids was more evident than that of the insecticide soap. Classification of the percentage of repellency (PR) values according to Juliana and Su (1983), indicated that insecticide soap ranked as class $\mathrm{I}(\mathrm{PR}=0.1-20 \%)$ within an exposure time of 3 to $18 \mathrm{~h}$. In contrast, the PR values of imidacloprid were classified as class III for all observation times and these values were in classes II and III with thiacloprid (Table 2).

\section{DISCUSSION}

Imidacloprid and thiacloprid as conventional neonicotinoid insecticides are effective against aphids and other 


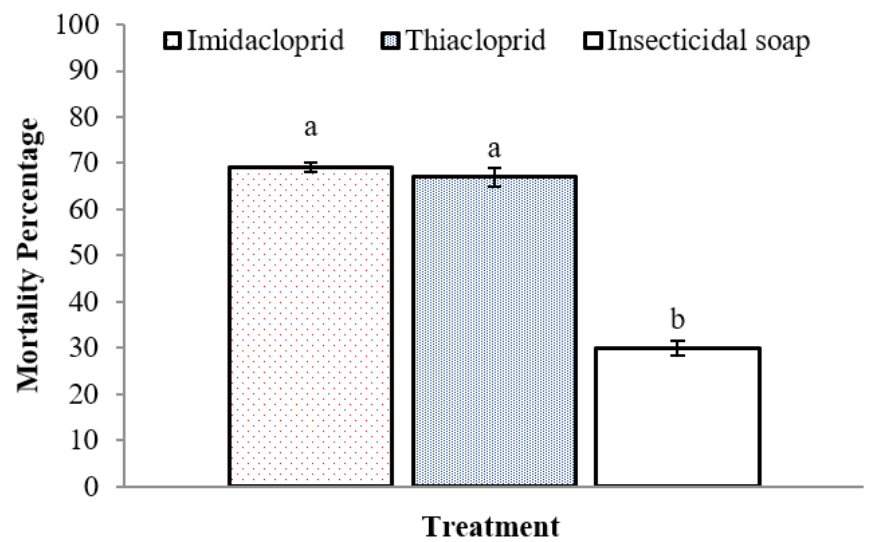

Figure 2: Mean percentage mortality ( \pm SE) of Aphelinus mali exposed to imidacloprid, thiacloprid and a coconut-derived insecticide soap after feeding on contaminated sugary water in filter papers within $72 \mathrm{~h}$. Mortalities (\%) compared with Tukey's test at $p \leq 0.05$ in which same letters are not significantly different

Table 2: Percentage of repellency (PR) of imidacloprid, thiacloprid and coconut-derived insecticide soap against Aphelinus mali at different exposure times at the Y-tube olfactometer using sprayed apple leaves as volatile sources

\begin{tabular}{|c|c|c|c|c|c|c|}
\hline \multirow[b]{2}{*}{ Insecticide } & \multicolumn{6}{|l|}{ Time (h) } \\
\hline & 3 & 6 & 9 & 12 & 15 & 18 \\
\hline Imidacloprid & 49.340 (III) & 48.564 (III) & 52.625 (III) & 47.965 (III) & 36.833 (III) & 53.118 (III) \\
\hline Thiacloprid & 43.593 (III) & 33.359 (II) & 38.121 (II) & 35.034 (II) & 40.551 (III) & 38.039 (II) \\
\hline Insecticide soap & $14.268(\mathrm{I})$ & 10.69 (I) & $15.992(\mathrm{I})$ & $17.417(\mathrm{I})$ & 14.276 (I) & $16.685(\mathrm{I})$ \\
\hline
\end{tabular}

Classification of PR values followed that cited in Juliana and Su (1983): class 0 (PR $=0.1 \%)$, class I ( $P R=0.1-20 \%)$, class II (PR $=20.1-40 \%)$, class III $(\mathrm{PR}=40.1-60 \%)$, class IV $(\mathrm{PR}=60.1-80 \%)$ and class V $(\mathrm{PR}=80.1-100 \%)$.

sap-sucking insects. However, insect natural enemies and pollinators such as honeybees, Apis mellifera L., are the later reported to be affected by the exposure to imidacloprid and thiacloprid (Schmuck et al., 2001; Blacquiere et al., 2012; Fischer et al., 2014). Toxicity of imidacloprid and thiacloprid to eggs, N1 and N5 nymphs and adults of the predatory bug, Deraeocoris lutescens (Schilling, 1837) (Hemiptera: Miridae), via residual contact was investigated and results showed that all stages were susceptible to these chemicals (Azimizadeh et al., 2012). Sublethal concentrations of imidacloprid reduced the longevity and the fecundity of females of the seven-spot ladybird beetle Coccinella septempuntacta L. (Coleoptera: Coccinellidae). Moreover, similar effects were noticed on the F1 generation, i.e., the progeny of the exposed individuals (Xiao et al., 2016). In the study of Martinou et al. (2014), the direct, residual and oral toxicity of thiacloprid were evaluated against $\mathrm{Mac}$ rolophus pygmaeus (Rambur, 1839) (Hemiptera: Miridae) as a common generalist predator in Mediterranean agroecosystems. Along with lethal effects, thiacloprid caused an increase in resting and preening times of the predator Based on the significant acute toxicity of imidacloprid and thiacloprid against A. mali, results of the mentioned studies are consistent with the results of the present work. Accordingly, the use of these chemicals cannot be compatible with the activity of this parasitoid and thus they should be used properly taking into consideration its effects on non-target organisms for successful integrated pest management (IPM) strategies. However, they clearly had less toxicity than some organophosphate insecticides such as chlorpyrifos, diazinon and carbaryl, which have been categorized as "highly toxic" compounds by Bradley et al. (1997). Further, Rogers et al. (2011) reported that thiacloprid had no or low-level toxicity on A. mali in the contact toxicity with filter papers, while in the present study it showed low and moderate levels of toxicity in the bioassays with apple leaves and filter papers, respectively. Different experimental conditions and materials might contribute to the variations in results. For example, contact toxicity in the study of Rogers et al. (2011) was carried out by filter paper but in the present study leaf discs were used. Furthermore, according to results of the present work, thiacloprid showed less toxicity in bioassays 
with leaf discs than that with filter papers. It is worthy to mention that leaf spray pesticide application would provide more realistic orchard conditions, resulting in lower toxicity against $A$. mali.

The insecticide soap $\left(\right.$ Palizin $\left.^{\circ}\right)$, the coconut-derived pesticide, showed great potential in the management of insect pests and its toxicity and repellency against some insect pests have been recently acknowledged (Amiri-Esheli, 2009; Sadeghi et al., 2014; Sheibani \& Hassani, 2014). The side effects of the Palizin have not yet been reported before. Comparison of the Pali$\operatorname{zin}^{\star}$ and imidacloprid toxicity was made against cotton aphid (Aphis gossypii Glover, 1877) and its natural enemy (Aphidius colemani Viereck, 1912) (Ketabi et al., 2014). In this research, imidacloprid had a higher level of toxicity against both the aphid and the wasp than Palizin which consistent with the obtained findings.

\section{CONCLUSION}

Generally, the insecticide soap showed significantly less toxicity than tested chemicals in all bioassays. Furthermore, the repellent effects of insecticide soap were significantly lower than imidacloprid and thiacloprid applications. However, further studies should be conducted to assess the sublethal effects of Palizin ${ }^{\circ}$ on the behavior and reproduction-related traits that could influence the population dynamics of the parasitoid in the field. These aspects are particularly true in the case of novel bioinsecticides that are slower acting, and for which the evaluation of the sole acute toxicity could not really represent the true risk for biological control agents (Biondi et al., 2012 and 2013). Obtained findings, need to be validated under realistic field conditions, considering that the novel bioinsecticide Palizin is more suitable for the sustainable management of woolly apple aphid.

\section{REFERENCES}

Abbott, W.S. (1925). A method for computing the effectiveness of an insecticide. Journal of Economic Entomology, 18, 265-267. https://doi.org/10.1093/jee/18.2.265a

Amiri-Besheli, B. (2009). Toxicity evaluation of Tracer, Palizin, Sirinol, Runner and Tondexir with and without mineral oils on Phylocnistis citrella Stainton. African Journal of Biotechnology, 8, 3382-3386.

Azimizadeh, N., Ahmadi, K., Imani, S., Takalloozadeh, H. \& Sarafrazi, A. (2012). Toxic effects of some pesticides on Deraeocoris lutescens in the laboratory. Bulletin of Insectology, 65, 17-22. http://www.bulletinofinsectology.org/ pdfarticles/vol65-2012-017-022azimizadeh.pdf
Beers, E.H., Cockfield, S.D. \& Fazio, G. (2007). Biology and management of woolly apple aphid, Eriosoma lanigerum (Hausmann), in Washington state. IOBC/wprs Bulletin, 30, 37-42. http://agris.fao.org/agris-search/search. do? recordID $=$ US201301539197

Biondi, A., Desneux, N., Siscaro, G. \& Zappalà, L. (2012). Using organic-certified rather than synthetic pesticides may not be safer for biological control agents: selectivity and side effects of 14 pesticides on the predator Orius laevigatus. Chemosphere, 87, 803-812. https://doi.org/10.1016/j.chemosphere.2011.12.082

Biondi, A., Zappalà, L., Stark, J.D. \& Desneux, N. (2013). Do biopesticides affect the demographic traits of a parasitoid wasp and its biocontrol services through sublethal effects? PloS One, 8, e76548. https://doi.org/10.1371/journal. pone. 0076548

Biondi, A., Campolo, O., Desneux, N., Siscaro, G., Palmeri, V. \& Zappalà, L. (2015). Life stage-dependent susceptibility of Aphytis melinus DeBach (Hymenoptera: Aphelinidae) to two pesticides commonly used in citrus orchards. Chemosphere, 128, 142-147. https://doi.org/10.1016/j.chemosphere.2015.01.034

Blacquiere, T., Smagghe, G., Van Gestel, C.A.M. \& Mommaerts, V. (2012). Neonicotinoids in bees: a review on concentrations, side-effects and risk assessment. Ecotoxicology, 21, 973-992. https://doi.org/10.1007/s10646-012-0863-x

Bradley, S.J., Murrell, V.C., Shaw, P.W. \& Walker, J.T.S. (1997). Effect of orchard pesticides on Aphelinus mali, the woolly apple aphid parasitoid. Proceedings of the 50th New Zealand Plant Protection Conference, New Zealand. Available from: http://www.nzpps.org/journal/50/nzpp_502180. pdf, https://doi.org/10.30843/nzpp.1997.50.11356

Damalas, C.A. \& Eleftherohorinos, I.G. (2011). Pesticide exposure, safety issues, and risk assessment indicators. International Journal of Environmental Research and Public Health, 8, 1402-1419. https://doi.org/10.3390/ijerph8051402

Desneux, N., Decourtye, A. \& Delpuech, J.M. (2007). The sublethal effects of pesticides on beneficial arthropods. Annual Review of Entomology, 52, 81-106. https://doi. org/10.1146/annurev.ento.52.110405.091440

Desneux, N., Pham-Delegue, M.H. \& Kaiser, L. (2004). Effects of sub-lethal and lethal doses of lambda-cyhalothrin on oviposition experience and host-searching behaviour of a parasitic wasp, Aphidius ervi. Pest Management Science, 60, 381-389. https://doi.org/10.1002/ps.822

Desneux, N., Denoyelle, R. \& Kaiser, L. (2006). A multi-step bioassay to assess the effect of the deltamethrin on the parasitic wasp Aphidius ervi. Chemosphere, 65, 1697-1706. https://doi.org/10.1016/j.chemosphere.2006.04.082

Fischer, J., Müller, T., Spatz, A.K., Greggers, U., Grünewald, B. \& Menzel, R. (2014). Neonicotinoids interfere with specific components of navigation in honeybees. PloS One, 9(3), e91364. https://doi.org/10.1371/journal.pone.0091364

Heunis, J.M. \& Pringle, K.L. (2003). The susceptibility Aphelinus mali (Haldeman), a parasitoid of Eriosoma lanigerom to pesticides used in apple orchards in the Elgin area, western cape province, South Africa. African Entomology, 11, 91-96. http://agris.fao.org/agris-search/search. do? recordID $=$ ZA2003000540 
Juliana, G. \& Su, H.C.F. (1983). Laboratory studies on several plant materials as insect repellents for protection of cereal grains. Journal of Economic Entomology, 6, 154-157. https://doi.org/10.1093/jee/76.1.154

Ketabi, L., Jalalaizand, A. \& Bagheri, M.R. (2014). A study about toxicity of some herbal insecticides on cotton aphid (Aphis gossypii) and its natural enemy (Aphidius colemani) in laboratory and greenhouse. Advances in Environmental Biology, 8, 2855-2858. https://doi.org/10.1093/jee/76.1.154

Lordan, J., Alegre, S., Gatius, F., Sarasúa, M.J. \& Alins, G. (2015). Woolly apple aphid Eriosoma lanigerum Hausmann ecology and its relationship with climatic variables and natural enemies in Mediterranean areas. Bulletin of Entomological Research, 105, 60-69. https://doi. org/10.1017/S0007485314000753

Martinou, A.F., Seraphides, N. \& Stavrinides, M.C. (2014). Lethal and behavioral effects of pesticides on the insect predator Macrolophus pygmaeus. Chemosphere, 96, 167173. https://doi.org/10.1016/j.chemosphere.2013.10.024

Nerio, L., Olivero-Verbel, J. \& Stashenko, E. (2009). Repellency activity of essential oils from seven aromatic plants grown in Colombia against Sitophilus zeamais Motschulsky (Coleoptera). Journal of Stored Product Research, 45, 212-214. https://doi.org/10.1016/j.jspr.2009.01.002

Rogers, D.J., Sharma, N., Stretton, D.C. \& Walker, J.T.S. 2011. Toxicity of pesticides to Aphelinus mali, the parasitoid of woolly apple aphid. New Zeeland Plant Protection, 64, 235240. https://doi.org/10.30843/nzpp.2011.64.5960

Sadeghi, R., Jokar, M., Jamshidnia, A. \& Ebadollahi, A. (2014). Repellency of Palizin (Coconut Soap) with three laboratory techniques against five stored product insect pests. Archive of Phytopathology and Plant Protection, 47, 16861695. https://doi.org/10.1080/03235408.2013.855004

Schmuck, R., Schoning, R., Stork, A. \& Schramel, O. (2001). Risk posed to honeybees (Apis mellifera L, hymenoptera) by an imidacloprid seed dressing of sunflowers. Pest Management Science, 57, 225-238. https://doi.org/10.1002/ ps. 270

Sheibani, Z. \& Hassani, M.R. (2014). The toxicity investigation of the botanical insecticides on the common pistachio psyllid, Agonoscena pistaciae Burckhardt and Lauterer (Hemiptera: Psyllidae). Journal of Nuts, 5, 57-62.

Sterk, G., Hassan, S.A., Baillod, M., Sterk, G., Hassan, S.A., Baillod, M., Bakker, F., Bigler, F., Blümel, S., Bogenschütz, H., Boller, E., Bromand, B., Brun, J., Calis, J.N.M., Coremans-Pelseneer, J., Duso, C., Garrido, A., Grove, A., Heimbach, U., Hokkanen, H., Jacas, J., Lewis, G., Moreth, L., Polgar, L., Rovesti, L., Samsoe-Peterson, L., Sauphanor, B., Schaub, L., Stäubli, A., Tuset, J.J., Vainio, A., Van de Veire, M., Viggiani, G., Viñuela, E. \& Vogt, H. (1999). Results of the seventh joint pesticide testing programme carried out by the IOBC/WPRS-Working Group 'Pesticides and Beneficial Organisms'. Biocontrol, 44, 99-117. https://doi. org/10.1023/A:1009959009802

Su, M., Tan, X., Yang, Q., Zhou, H. and Wan, F. (2017). Relative efficacy of two clades of Aphelinus mali (Hymenoptera: Aphelinidae) for control of woolly apple aphid (Hemiptera: Aphididae) in China. Journal of Economic Entomology, 110, 35-40. https://doi.org/10.1093/jee/tow271

Wang, D.S., He, Y.R., Guo, X.L. \& Luo, Y.L. (2012). Acute toxicities and sublethal effects of some conventional insecticides on Trichogramma chilonis (Hymenoptera: Trichogrammatidae). Journal of Economic Entomology, 105, 1157-1163. https://doi.org/10.1603/EC12042

Williams, I.L., Price, L.D. \& Manrique, V. (2003). Toxicity of field-weathered insecticide residues to Anaphes iole (Hymenoptera: Mymaridae), an egg parasitoid of Lygus lineolaris (Heteroptera: Miridae), and implications for innovative biological control in cotton. Biological control, 26, 217-223. https://doi.org/10.1016/S1049-9644(02)00157-3

Xiao, D., Zhao, J., Guo, X., Chen, H., Qu, M., Zhai, W., Desneux, N., Biondi, A., Zhang, F. \& Wang, S. (2016). Sublethal effects of imidacloprid on the predatory seven-spot ladybird beetle Coccinella septempunctata. Ecotoxicology, 25, 1782-1793. https://doi.org/10.1007/s10646-016-1721-z 